\title{
“DE MIM MESMO SOU INIMIGO": EXÍLIO E SAUDADE NA ÉCLOGA II DE BERNARDIM RIBEIRO
}

\author{
Luís André Nepomuceno*
}

Resumo: O presente estudo analisa algumas questões históricas e filosóficas envolvidas na écloga II ("Jano e Franco") de Bernardim Ribeiro, incluída na sua editio princeps publicada em 1554, em Ferrara, por iniciativa de Abraão Usque, judeu português exilado na Itália. Até o séc. XIX, as éclogas tinham sido vistas como poesia de temática romanesca e amorosa, e apenas recentemente identificadas (juntamente com a Menina e moça, romance pastoril do mesmo autor) como obra de resistência judaica. Este trabalho pretende identificar as éclogas de Bernardim Ribeiro, em especial a "Jano e Franco", com as obras consolatórias sefarditas tão em voga na Península Ibérica do séc. XVI, buscando sua identidade literária e política especialmente na Consolação às tribulações de Israel, de Samuel Usque, ou em livros referenciais da cabala, como o Zohar.

Palavras-chave: Renascimento português; judaísmo; platonismo.

Em 1554, o judeu português Abraão Usque, exilado em Ferrara, na Itália, dava à estampa, na sua então famosa oficina tipográfica, a edição princeps das obras de Bernardim Ribeiro, incluindo num mesmo volume a novela Menina e moça, cinco éclogas, outros poemas de Bernardim já publicados no Cancioneiro Geral de Garcia de Resende, e por fim, a écloga Crisfal (atribuída ao poeta Cristóvão Falcão), acompanhada de uma carta, e de "outras cousas que entre lendo se poderam ver", conforme

* Centro Universitário de Patos de Minas. 
anunciava a portada que acompanhava o frontispício do livro. ${ }^{1}$ Seguir as complexidades filológicas que envolvem essa edição definitivamente não faz parte dos objetivos deste trabalho. Há dois manuscritos bernardinianos e três edições quinhentistas de suas obras, e entre eles, existem divergências de estilo, de base textual e até mesmo de imaginário cultural. Mas compreender o cenário histórico que deu origem à edição de 1554 parece um motivo extraordinariamente relevante para desenvolver as bases interpretativas da écloga II, "Jano e Franco", matéria de análise deste trabalho.

A biografia de Bernardim Ribeiro é um verdadeiro mistério. O fato de seu livro ter recebido os favores especiais de um judeu português (a quem ele talvez não tenha conhecido pessoalmente) tem levado historiadores a uma identificação quase inevitável entre Bernardim e o criptojudaísmo da Península Ibérica. O poeta teria sido um judeu forçadamente convertido ao cristianismo (portanto um cristão-novo) e posteriormente reconvertido ao judaísmo, logo depois das perseguições e do êxodo dos sefardins na primeira metade do quinhentismo. ${ }^{2} \mathrm{Um}$ ano antes da edição de Bernardim, Abraão Usque tinha dado à estampa um de seus mais importantes livros, a Consolação às tribulações de Israel, de Samuel Usque

\footnotetext{
${ }^{1}$ No volume original, a informação contida na tábua descritiva das matérias do livro ("que dizem ser de Cristóvão Falcão, ho que parece alludir ho nome da mesma Ecloga") coloca em destaque um enigma que o próprio editor quis deixar em aberto, e que acabou provocando polêmicas futuras sobre a identidade de Falcão e sobre a autoria do poema. Delfim Guimarães, em 1908, pensou ter descoberto os segredos da edição de 1554, presumindo que Cristóvão Falcão fosse o próprio Bernardim Ribeiro, e que sua écloga Crisfal seria um jogo anagramático com "crisma" e "falso" (GUIMARÃES. Bernardim Ribeiro (o poeta crisfal)). Mesmo na crítica posterior ao biografismo romântico, António José Saraiva julgou pertinente incluir a Crisfal (mas não a carta) entre as obras de Bernardim Ribeiro (SARAIVA. Poesia e drama, p. 52). O livro de António Cândido Franco põe sobre a questão uma sentença insolúvel (FRANCO, Oessencial sobre Bernardim Ribeiro, p. 47).

${ }^{2}$ MACEDO. Bernardim Ribeiro, p. 417.
} 
(por muito tempo tido como seu irmão), ${ }^{3}$ e até 1559 , terá contribuído com a tipografia portuguesa quinhentista com pelo menos 29 livros publicados em cinco anos, todos eles ligados à matéria judaica, incluindo-se aí também um dos mais famosos deles, a Bíblia de Ferrara, em espanhol. Não é provável que Bernardim Ribeiro tenha sido uma exceção única de matéria nãojudaica nos interesses do tipógrafo português, a julgar pelo conteúdo ideológico de seus projetos editoriais.

Ferrara naquele tempo era um centro importante da comunidade judaica. No séc. XVI, chegariam ali grandes aglomerações de judeus sefardins, boa parte vinda de Portugal ou da Espanha, em consequência das intolerâncias e perseguições iniciadas na Península Ibérica no fim do séc. XV e mantidas por todo o quinhentismo. Bernardim Ribeiro que, conforme a tradição, nasceu entre 1482 e 1487, teria passado uma infância de perseguições e muito provavelmente deve ter sentido o rigor impiedoso de cada uma das práticas de intolerância aos judeus em Portugal e na Espanha, no começo da era moderna. Em 1492, com a expulsão dos sefardins da Espanha, muitos deles se refugiam em Portugal, inicialmente recebidos por D. João II, movido por interesses econômicos, prática tolerante que durará por pouco tempo. Pressionado pelos reis católicos da Espanha, D. Manuel irá assinar o decreto de expulsão dos judeus de Portugal, em 1496, exigindo deles o exílio ou a conversão. É a era dos cristãos-novos

\footnotetext{
${ }^{3}$ António Manuel Lopes Andrade nos informa que Samuel Usque, Abraão Usque e Salomão Usque estiveram entre os mais notáveis "Senhores do Desterro de Portugal", mas que é difícil precisar a relação familiar entre eles: "O avanço da investigação, porém, ainda não foi suficiente para aclarar por completo que tipo de relação familiar, se acaso existe, pode ser estabelecida entre os Usque. Ainda assim, é possível avançar com alguns dados que nos permitem analisar, com relativa segurança, a questão das supostas relações familiares". Por fim, emenda o historiador: "Provou-se recentemente que resulta impossível Abraão ser pai ou irmão de Samuel Usque" (ANDRADE. Os senhores do desterro: judeus portugueses em Veneza e Ferrara em meados do século XVI, p. 78 e 79).
} 
que deverão suportar as políticas de intolerância por pelo menos três séculos, especialmente a partir de 1536, quando se publica a primeira bula inquisitorial, que levaria à constituição do primeiro tribunal do Santo Ofício em Lisboa. Os anos de 1540-1550, em que Bernardim Ribeiro já teria prontas as suas éclogas, serão marcados por um grande êxodo hebraico português. François Soyer ${ }^{4}$ esclarece que Manuel I queria a conversão de todos os judeus, sonhando com o primeiro reino inteiramente cristão da história. Muitos judeus preferiram o abandono do reino, o que teria causado um choque econômico para o país, embora a maioria judaica tivesse preferido a conversão. ${ }^{5}$

No meio das perseguições aos marranos espanhóis e aos cristãos-novos portugueses, é possível que o tribunal tenha caçado mais judeus do que efetivamente existiam na Península Ibérica. Fala-se ainda hoje de uma "fábrica de judeus", já que um século depois da suposta "limpeza de sangue", iniciada a partir de 1536, ainda crescia muito o número de suspeitos de judaísmo. ${ }^{6}$ Onde estaria Bernardim Ribeiro à época das primeiras perseguições? Que relação teria a sua suposta "ruína" na corte portuguesa (mencionada por seu amigo Sá de Miranda, na écloga "Aleixo") com os acontecimentos históricos da intolerância antissemita? Antonio José Saraiva acredita numa conversão religiosa que, imposta inicialmente pelo poder, acaba por se diluir ao longo da história, de tal forma a haver, já no final do séc. XVI, uma grande

\footnotetext{
${ }^{4}$ SOYER. The persecution of the Jews and Muslims of Portugal: King Manuel I and the end of religious tolerance (1496-7), p. 193-194.

${ }^{5}$ Até 1496, a população de judeus em Portugal deveria ser de 30.000 pessoas, o que equivaleria a $3 \%$ de toda a população (SOYER. The persecution of the Jews and Muslims of Portugal, p. 44). Quantos judeus abandonaram o país é difícil imaginar: a estimativa de Lúcio de Azevedo de que 120.000 judeus devem ter abandonado o país durante as primeiras décadas do séc. XVI parece bastante exagerada (AZEVEDO. História dos cristãos-novos portugueses, p. 109).
}

${ }^{6}$ SARAIVA. Poesia e drama, p. 121. 
comunidade de cristãos-novos convertidos com sinceridade ao cristianismo. ${ }^{7}$ Caso como o dos Usque, judeus portugueses ortodoxos que cultivaram a prática e disseminaram suas crenças, seria uma exceção de persistência na lei de Moisés.

Pensando nesse cenário histórico de perseguições e considerando que a écloga é por natureza um gênero poético de motivos enigmáticos, ${ }^{8}$ é possível entrever certas dificuldades na análise da poesia pastoril de Bernardim, publicada em 1554. José Augusto Bernardes considerou que, nas éclogas bernardinianas, a típica estrutura dialógica do gênero faz nascer uma dicotomia sempre perceptível na contraposição ideológica de dois pastores: "um deles, pelo menos, é um pastor desterrado e acometido por desventuras amorosas e o outro, em maior ou menor sintonia afectiva com o primeiro mas, por várias razões, menos afectado na sua lucidez, procura atenuar o sofrimento do interlocutor recorrendo a estratégias racionalizadoras". ${ }^{9}$ A observação de Bernardes é útil e perspicaz, e parece funcionar para todas as composições de Bernardim, mesmo naquelas em que os dois personagens se veem "afetados na sua lucidez". Nas éclogas III e V, por exemplo, ambos os interlocutores vivem experiências amorosas dramáticas, embora curiosamente cada um deles seja capaz de organizar para o outro um discurso coerente de oposição racional.

Na écloga I, Pérsio, em diálogo com Fauno, lamenta a perda do amor de Maria, levada a outras terras para se casar com

\footnotetext{
${ }^{7}$ SARAIVA. Poesia e drama, p. 38.

${ }^{8} \mathrm{O}$ surgimento da écloga no Renascimento respondia a um antigo preceito, estabelecido por Petrarca, no séc. XIV, de que este gênero poético traz consigo enigmas que apenas o autor poderá decifrar. A formulação de Petrarca está na carta Fam. X 4 (de 1349), dedicada ao irmão Gherardo: ali Petrarca comenta com o irmão os motivos que estiveram por trás da elaboração do seu Bucolicum carmen (especialmente o primeiro poema), revelando informações pessoais, escondidas por meio de enigmas (PETRARCA. Letters on familiar matters (Rerum familiarium libri IX-XVI), p. 69-75).

${ }^{9}$ BERNARDES. O bucolismo português, p. 31.
} 
pastor mais rico, enquanto Fauno tenta consolar o amigo com argumentos racionais e coerentes, voltados a uma visão estoica de controle da vontade e dos ímpetos: "agora fujo da gente / não vejo triste ninguém / que viva mais descontente", diz o desventurado Pérsio, num ímpeto de tristeza e misantropia. ${ }^{10}$ "Crê-me tu, Pérsio, a mim, que não há maior vencer / que vencer-se homem a si”, responde-lhe o amigo Fauno, que aqui fará o papel do bomo cogitans, aquele que pensa e ordena a meditação, a prudência, lembrando o adágio máximo do estoicismo clássico, em que o homem deve ser capaz de controlar os seus ímpetos. Na écloga II, matéria de análise deste trabalho, Jano abandona o Torrão, sua terra natal, fugindo da seca e em busca de melhores condições de vida, para no exílio apaixonar-se desvairadamente pela pastora Joana. No primeiro e único encontro, às margens do rio, tenta abordá-la, mas a mocinha é surpreendida e foge, deixando um sapato. Jano, arrebatado e já sem lucidez, desfalece e só irá despertar, quando da chegada do amigo Franco, a quem ele então confidencia a súbita experiência do drama amoroso. Franco, a exemplo do Fauno da primeira écloga, fará o papel do consolador, embora não tenha daquele a capacidade prática e sistematizadora da filosofia estoica.

A écloga III parecer quebrar o quadro da dicotomia desvario $\times$ lucidez: Amador e Silvestre se equivalem e se identificam no sofrimento amoroso e no drama do exílio. Apaixonados e desterrados ambos, só lhes restam agora o lamento e a tristeza, acompanhados, muito embora, da promessa de buscar novas terras. A écloga IV, embora seja um monólogo e não um diálogo, também não rompe com a dicotomia típica da estrutura bernardiniana. Jano, possivelmente aquele mesmo da écloga II, é levado agora a uma tristeza aguda e persistente, por amor a Dina,

\footnotetext{
${ }^{10}$ As edições de Bernardim Ribeiro consultadas para este artigo foram: Obras completas. Vol. I: Menina e Moça. Vol. II: Éclogas, 1982; e Obras de Bernardim Ribeiro, 2010. As citações aqui referidas são da segunda.
} 
e vê-se arrastado a terras distantes. A relação dialógica se apresenta quando Jano recorda certa conversação mantida com Africano, num passado impreciso, em que este pastor (mais sábio e mais velho) recomendava-lhe proteger-se do amor e distanciar-se das riquezas. Africano será também o mesmo bomo cogitans que Fauno representara na écloga I: com ares e discursos de filósofo, é o pastor da meditação, do autoexame moral, da lucidez, e mais que isso, é o pastor da consolação. Por fim, na écloga V, Bernardim Ribeiro põe em cena uma vez mais dois pastores exilados que vivem o mal de amor: Ribeiro sente saudades da Ribeira, a amada deixada em sua terra natal, a qual abandonara forçosamente, e Agrestes sente o mal do ciúme, porque, agora no exílio, lamenta a perda da amada que teria se entregado aos braços de outro, a exemplo do que acontecera com Pérsio, na écloga I. Ribeiro e Agrestes se equivalem na dor e no desvario, mas curiosamente ambos assumem, cada um a seu tempo, o discurso da consolação.

Numa síntese rápida, porém esclarecedora, poderíamos considerar o seguinte: em todas as éclogas de Bernardim Ribeiro, vemos a interlocução de dois pastores, em que um deles (ou ambos, em alguns casos) vê-se atormentado pelo sofrimento amoroso e o outro lhe serve de consolador. Mesmo nas circunstâncias em que os dois interlocutores se veem atribulados pelo mesmo mal, ou por diferentes males, ambos assumem, cada um a seu tempo, a tarefa de consolar o outro. Em outras palavras, um esquema invariável: a tribulação e o consolo. Também são frequentes nas éclogas de Bernardim: a fatalidade trágica da paixão amorosa; a mudança súbita de um quadro existencial; o sentimento profundo e persistente da saudade, em geral estimulada pela distância da mulher amada ou da terra natal; e por fim, uma espécie de estranhamento de si mesmo, na medida em que os personagens, vivendo experiências bruscas de aprisionamento amoroso, já não reconhecem seus próprios sentimentos, como se tivessem se tornado inimigos de si mesmos ou alheios a sua própria identidade. O estranhamento de si torna-se tema recorrente e complexo na literatura de Bernardim Ribeiro. Fauno, na écloga I, dirá ao desesperado Pérsio: “[o mal] então pôs-te em tal 
extremo / que te fez de ti alheio". Jano também admite na écloga II, conversando consigo: "Eu mesmo a mim mesmo estranho", e depois repetirá esse discurso invariável na écloga IV: "de mim eu me desavim, / e pois eu me sou imigo / quem me vingará de mim?", ${ }^{11}$ para encontrar resposta no discurso de Ribeiro, na écloga V: "De mim mesmo sou inimigo, / de mim me quero guardar", ou no discurso de Agrestes, na mesma écloga: "que de mim mesmo sou imigo / para me mais condenar". ${ }^{12}$

Numa nova síntese, ainda mais precisa, os personagens das éclogas de Bernardim Ribeiro são indivíduos sofregamente marcados por um corte existencial, motivado pelo amor, pela saudade ou pelo exílio (ou por todos eles ao mesmo tempo), o que os leva a um estranhamento de sua própria identidade e à busca de um consolo para essa tribulação. A julgar pelo fato de Bernardim ter sido visto por historiadores e críticos como cristão-novo, ou mesmo judeu, o quadro acima descrito não é espantoso. ${ }^{13}$ Trata-se

${ }^{11}$ RIBEIRO. Obras de... p. 227, 242 e 276.

${ }^{12}$ Algumas décadas antes da primeira edição das éclogas, Bernardim Ribeiro teria publicado no Cancioneiro Geral de Garcia de Resende, em 1516, um vilancete enigmático e engenhoso, de fundo filosófico, em que dizia: "Entre mim mesmo e mim / não sei que se alevantou / que tão meu imigo sou" (RIBEIRO. Obras de... p. 210). Helder Macedo, num importante estudo sobre a obra de Bernardim Ribeiro, especialmente da novela Menina e moça, propõe que o estranhamento de si mesmo se explica porque o " $\mathrm{eu}$ pode ficar dividido e oposto a si mesmo numa situação existencial concretamente ameaçada, como resultado de irreconciliação de opções materialistas anteriores com a qualidade espiritual do amor revelado como um 'bem" (MACEDO. Do significado oculto da Menina e Moça, p. 43).

13 Em livro bastante provocador de 1931, Teixeira Rego foi o primeiro a considerar inevitável o judaísmo de Bernardim Ribeiro (TEIXEIRA REGO. Estudos e controvérsias, pp. 165-170). Observava o crítico, por exemplo, que em toda a obra de Bernardim, não há qualquer referência a ritos cristãos, nem a nomes como Jesus, Cristo, Maria ou aos santos católicos, o que, aliás, denunciaria a segunda edição da Menina e moça (Évora, 1557) como apócrifa, já que nela ocorre uma nomenclatura cristã. 
de uma motivação essencialmente judaica, se considerarmos o cenário político de Portugal no séc. XVI, apresentado atrás.

Consideradas as temáticas acima, a écloga II é clássica e pródiga de elementos bernardinianos. Jano, o personagem-pastor em torno do qual gira toda a trama, é o homem no centro de uma crise de identidade: saiu de sua terra natal, o Torrão, em busca de melhores condições de vida, e agora no Alentejo, vê-se diante de um amor avassalador e impulsivo pela pastora Joana. Mas terá sido motivado este amor por um único e fugaz encontro com a moça, às margens do rio, quando a pastora, guardadora de patos, em momento de intimidade, se contemplava nas águas. A imagem volta-lhe à memória, em fulgurações intensas, como um raio que lhe divide a consciência. Momentos depois, relata ao amigo Franco a decisiva experiência daquele dia. Franco, depois de lhe ouvir a história, entoa uma cantiga sobre o amor, o exílio e a saudade.

A temática da peregrinação, que está igualmente nas outras éclogas de Bernardim, não é nova na literatura portuguesa quinhentista: por influência da Arcadia (1504), o romance de Jacopo Sannazaro, em que o pastor Sincero abandonava sua Nápoles para peregrinar entre as montanhas da Arcádia, convivendo com homens rústicos, enfrentando adversidades e aprendendo as lições da natureza, também Camões, Jorge de Montemayor, Fernão Álvares do Oriente ou Diogo Bernardes estiveram às voltas com pastores errantes, lidando com a matéria da saudade e da desilusão amorosa. ${ }^{14} \mathrm{Na}$ obra de Bernardim Ribeiro, no entanto, o tema, reincidente demais, por vezes obsessivo, adquiriu contornos visivelmente ideológicos, mantendo diálogos profundos com outros livros editados por judeus à mesma época.

Jano é o peregrino que, saindo de uma condição social de vida miserável, encontra as doces misérias do amor: tomado pelo sentimento amoroso, Jano já não se reconhece, torna-se inimigo de si mesmo, perde a razão e o discernimento. "Eu mesmo a mim

${ }^{14}$ NEPOMUCENO. Literatura e exílio: cristãos-novos na Renascença Portuguesa, p. 343-357. 
mesmo estranho", dirá o pastor para si, e depois: "estou em tanto desvario / que não me entendo comigo". ${ }^{15}$ Nas poesias de Bernardim, e mesmo na novela Menina e moça, o autor coloca em cena personagens que, em essência, perderam uma condição de vida espiritual que ficou no passado, "a glória que é já perdida", como diz Ribeiro, na écloga $V^{16}$ A mulher amada, ou a pastora, símbolo do espírito divino, apresenta-se ao pastor como revelação, como fulguração do esplendor de Deus aos homens, para depois sair de cena e manter-se apenas como persistência de uma memória, a provocar um eterno sentimento de saudade. O próprio Jano cai desfalecido ao ter diante de si a visão de Joana (na terceira parte da Menina e moça, o cavaleiro Avalor também desfalece quando tem diante de si a imagem de sua amada Arima). O corte existencial na vida desses personagens se torna mais dramático, porque a revelação de Deus, pela fulguração da imagem da mulher, mostra-se profundamente niilista, uma vez que essa mesma mulher amada se torna uma espécie de "divindade ausente", gerando a desesperança fomentada pelo sentimento do "encontrar para perder", no dizer de Helder Macedo. ${ }^{17}$ A vivência espiritual dos pastores de Bernardim, portanto, é a amarga experiência de uma perda, é a compreensão da existência de um bem que se revela e que depois se ausenta, deixando no registro da memória a fatalidade de um encontro revelador. O poeta faz questão de definir esse encontro com a pastora como uma fatalidade trágica e como o desenlace de uma profecia: "o que há de ser há de ser, / não se lhe pode fugir, / defender, nem esconder", lamenta-se Jano. ${ }^{18} \mathrm{E}$ lembre-se que, na écloga II, o caráter profético do encontro amoroso e da revelação divina está ainda mais sedimentado na figura do Piério, o velho pastor que profetizara o exílio e os tormentos de Jano.

\footnotetext{
${ }^{15}$ RIBEIRO. Obras de... p. 242 e 243.

${ }^{16}$ RIBEIRO. Obras de... p. 289.

${ }^{17}$ MACEDO. Bernardim Ribeiro, p. 417

${ }^{18}$ RIBEIRO. Obras de... p. 248.
} 
Nosso apaixonado pastor, a exemplo de outros personagens bernardinianos, vive na solidão da saudade (ainda que seja a curta saudade de uma visão que tão há pouco se revelou) e na esperança de retorno à amada e à terra natal, em ares proféticos e consolatórios, vivendo na saudade a contradição entre "angústia de não chegar e prazer de prosseguir". ${ }^{19}$ A saudade, temática essencialmente judaica, é também um dos mais expressivos recursos da filosofia platônica, que, aliás, por séculos ajudou a sustentar as bases da própria mística judaica. Bernardim Ribeiro, como não raro ocorre entre os poetas do quinhentismo português, por certo deve ter conhecido os livros centrais do platonismo e do neoplatonismo, ou pode ter tido ciência da filosofia neoplatônica por meio da própria formação judaica. ${ }^{20}$ Tema substancial dos neoplatônicos foi a reminiscência, tão ensinada por Sócrates, nos diálogos de Platão. Ainda que o filósofo português Leonardo Coimbra (a exemplo de tantos outros pensadores) faça a distinção entre a saudade portuguesa e a reminiscência platônica como essências diversas, ${ }^{21}$ na medida em que a primeira é restrita à

19 TEIXEIRA. A filosofia da saudade, p. 126.

${ }^{20}$ Aida Santos arrisca a dizer que a cultura literária de Bernardim teria sido "mais rica do que a que lhe tem sido imputada", o que a obra não parece desmentir (SANTOS. A écloga V de (ou sobre?) Bernardim Ribeiro, p. 289315). António José Saraiva, por sua vez, aponta-lhe influências "escolásticas e dialéticas", na sua capacidade de perceber o mundo a partir de relações entre subjetividade e objetividade (SARAIVA. Poesia e drama, p. 85 e segs). A julgar pela formação dos humanistas judeus portugueses de seu tempo (Samuel Usque ou Leão Hebreu, por exemplo), seria possível rastrear um saber profundamente erudito, sustentado no sincretismo filosófico, transitando entre platonismo, judaísmo rabínico, poesia humanista etc.

${ }^{21}$ TEIXEIRA. A filosofia da saudade, p. 38. Para uma reflexão profunda e original sobre a saudade metafísica ou transcendente na cultura portuguesa, ou seja, a saudade como "nostalgia de Deus", ver: COSTA. Saudade, unidade perdida, unidade reencontrada, p. 77-155. Para outras considerações sobre a saudade na cultura portuguesa, consulte-se ainda: VASCONCELOS. A saudade portuguesa, p. 43-60. 
experiência subjetiva, não deixa de haver aí, pelo menos na literatura de Bernardim, uma proximidade inevitável, o que leva à compreensão de que a vivência da saudade no indivíduo (no caso de Jano, por exemplo) adquire o contorno de um drama social e histórico das comunidades judaicas, mas também as feições de um processo puramente espiritual e universal.

Platão, na sua distinção entre os dois mundos (o sensível e o inteligível), ensina - pelas palavras de Sócrates - que só pela reminiscência o homem é capaz de perceber, mesmo palidamente, que a beleza deste mundo é espelho da beleza do mundo perfeito. É esta a lição que está no Fédon, por exemplo, quando Sócrates, pouco antes da morte, argumenta sobre a natureza da alma (Fédon, 74c-74e). ${ }^{22}$ No Mênon, o filósofo irá mostrar que a alma, lembrando-se das verdades do mundo perfeito (de onde ela deriva), já tem em si o conhecimento da verdade "das coisas que são" em nós mesmos (Mênon, 81c-86d). ${ }^{23}$ A reminiscência é a única forma de que a alma dispõe para recuperar as estruturas ontoepistemológicas de que esta própria alma se alimentava no mundo divino. ${ }^{24}$

${ }^{21}$ TEIXEIRA. A filosofia da saudade, p. 38. Para uma reflexão profunda e original sobre a saudade metafísica ou transcendente na cultura portuguesa, ou seja, a saudade como "nostalgia de Deus", ver: COSTA. Saudade, unidade perdida, unidade reencontrada, p. 77-155. Para outras considerações sobre a saudade na cultura portuguesa, consulte-se ainda: VASCONCELOS. A saudade portuguesa, p. 43-60.

${ }^{22}$ PLATÃO. Diálogos, Vol. III: Fedro. Eutífron. Apologia de Sócrates. Críton. Fédon, p. 212-213.

${ }^{23}$ Trata-se do famoso episódio em que Sócrates demonstra a Mênon que mesmo um escravo é capaz de apreender conceitos abstratos de geometria, quando lhe são feitas perguntas sobre a matéria, pois que sua alma já tem em si o conhecimento dessa verdade. (PLATÃO. Diálogos, Vol. V: O banquete. Mênon. Timeu. Crítias, p. 127-137).

${ }^{24}$ SANTOS. Para ler Platão, tomo II: O problema do saber nos diálogos sobre a teoria das formas, p. 17. Na verdade, a reminiscência é a via teórica que explica a percepção da idealidade pela alma como distinta da experiência vivida. Daí a 
Mas é possível que a teoria da reminiscência tenha chegado a Bernardim Ribeiro pelo filtro dos neoplatônicos renascentistas, ou mesmo de Plotino, filósofo que teve papel preponderante no judaísmo. Numa imagem memorável das Enéadas, Plotino dizia que as almas se distanciaram de Deus por vontade própria, perdendo até mesmo a lembrança de sua origem divina, assim como "uma criança que é retirada de casa quando ainda muito pequena e permanece longe por muitos anos não saberá quem são seus pais, nem quem ela mesma é". ${ }^{25}$ O próprio Bernardim Ribeiro pensaria uma metáfora muito semelhante no caput de sua novela Menina e moça, quando a personagem dizia: "Menina e moça me levaram de casa de minha mãe para muito longe". ${ }^{26} \mathrm{~A}$ imagem do desterro do homem em relação a Deus, somada à lembrança que têm as almas de uma beleza arquetípica, é tema recorrente em Plotino. Na Enéada IV 8, por exemplo, o filósofo alexandrino, apoiado em Pitágoras, Empédocles e Platão, argumenta sobre o exílio da alma, dizendo que esta está "sepultada" ou "acorrentada" no corpo, como numa prisão. ${ }^{27}$ Plotino teve larga aceitação entre filósofos e poetas neoplatônicos renascentistas, especialmente depois que Marsilio Ficino verteulhe as Enéadas completas para o latim entre 1484-1492, mas foi particularmente entre judeus a sua farta disseminação, o que se explica pela identificação arcaica entre judaísmo e platonismo, desde os primórdios das interpretações talmúdicas e rabínicas. ${ }^{28}$

teoria da existência anterior da alma e sua imortalidade, e a percepção platônica de que a verdade não está neste mundo, com o seu jogo de aparências.

${ }^{25}$ PLOTINO. Tratados da Enéadas, p. 69.

${ }^{26} \mathrm{Na}$ edição de Évora (1557), lê-se "Menina e moça me levaram de casa de meu pai para longes terras" (RIBEIRO. Obras completas, vol. I, p. 1).

${ }^{27}$ PLOTINO. Tratados das Enéadas, p. 82-83.

${ }^{28}$ REALE. História da filosofia grega e romana, Vol. 8: Plotino e neoplatonismo, p. 24-25. Reale já explica que na base da metafísica plotiniana ("a interioridade e a concepção do fim supremo do homem posto na união místico-estática com Deus") encontra-se quase certa a influência de Filo, o Judeu. Mas o contrário 
No pensamento de Plotino, "a alma congrega em si a capacidade de 'esquecer' a si mesma e um desejo de contemplação eterno, de pura racionalidade. A vida da alma está marcada pela 'saudade' e recordação de sua pátria perdida". ${ }^{29}$

Frente a essa confluência de linguagens filosóficas, especialmente advindas do neoplatonismo, o judaísmo sefardita da Península Ibérica foi uma das raras vertentes judaicas a reafirmar e consolidar a ponte entre revelação judaica e razão filosófica grega, iniciada por Fílon de Alexandria. Entre os peninsulares, sobretudo a partir do séc. XI, o judaísmo está diante de um dilema, em que se deve optar ou pela Torá ou pela filosofia grega, sabendo-se de antemão que o logos grego jamais teria o alcance da linguagem reveladora do livro sagrado. ${ }^{30}$ Mas a cabala sefardita, que vai estimular conceituações presentes no Zohar, na Consolação de Usque, ou mesmo nas éclogas de Bernardim (em que o exílio da alma e a reminiscência do mundo divino são princípios da verdade), sustenta-se teoricamente no neoplatonismo, eventualmente no pitagorismo, mesmo tendo em vista a sacralidade inviolável e reveladora da Torá.

Voltando à écloga de Bernardim Ribeiro, consideremos que o pastor Jano se revela como o modelo da típica experiência do desterro judaico, mas ao mesmo tempo, como a vivência do ser que traz em si a reminiscência platônica. Joana, a pastora que divide em duas fendas inconciliáveis a sua consciência, é uma fulguração que se lhe revela divina, mas que sai de cena, uma vez cumprido o seu papel revelador da divindade - como, de resto, acontece com outras figuras femininas de Bernardim. Sua imagem

também se deu: Plotino teve ampla aceitação entre filósofos judeus (BAL. Silêncio e contemplação, p. 148). Também Reynholdo Ullmann esclarece que a ideia da descida e do retorno ao Uno, base essencial do pensamento plotiniano, foi utilizada por judeus a partir do séc. VII (ULLMANN. Plotino, p. 207).

29 BEZERRA. Compreender Plotino e Proclo, p. 93.

${ }^{30}$ GOMES. A filosofia bebraico-portuguesa, pp. 47-53. 
desencadeará em Jano um ponto de convergência para a autoanálise e, depois de seu desaparecimento, Joana resta tão somente como uma alegoria. A considerar os nomes dos dois como versões masculina e feminina de um mesmo nome, "Jano também o nome do deus bicéfalo que olha em duas direcções ao mesmo tempo - não se teria enganado ao reconhecer Joana como o seu amor, a versão feminina de si". ${ }^{31}$ Jano e Joana são, portanto, os dois polos de um mesmo ser, e ela representa o que há de divino na natureza dele, ainda que seja o lado divino desterrado no mundo da matéria. Era essa a lição contida no Zobar, ou $O$ livro do esplendor, volume da mística judaica que teve sua primeira edição impressa em Mântua em 1558 (portanto, cinco anos depois da Consolação de Usque, e seguindo a trilha dos livros consolatórios), mas com ampla circulação entre judeus sefardins desde o seu primeiro aparecimento no séc. XIII, por iniciativa de Moisés de Leon. ${ }^{32} \mathrm{O}$ Zohar ajudou a difundir a concepção mística da shekinab, como a "Senhora que cuida do palácio do Rei Supremo", a face divina e materna da presença de Deus entre os homens. Segundo o livro profético, a evolução do homem é um processo em que o polo feminino da divindade (shekinab) se une ao polo masculino (Kether) numa representação mística que poderia ser identificada com as Núpcias alquímicas de Christian Rosenkreuz, ou com a união do feminino e do masculino no Cântico dos cânticos. Mas o Zohar, inspiração quase certa para

\footnotetext{
${ }^{31}$ MACEDO. Do significado oculto da Menina e moça, p. 28.

${ }^{32}$ Moisés de Leon afirmava que o autor do livro era Shimon ben Yohai, um místico que viveu entre os sécs. II e III, mas não existe na história qualquer manuscrito comprobatório do texto de Yohai, o que leva à evidente constatação de que o livro profético era mesmo do próprio Leon. Com seu estilo simples e casual, muito eventualmente hermético, o Zohar, imenso tratado cabalístico tornou-se um livro popular entre os marranos na Espanha e em Portugal, e alcançaria ainda mais êxito com sua publicação na Itália, especialmente entre os cristãos-novos exilados, devido sobretudo a seus ares messiânicos e consolatórios.
} 
Bernardim Ribeiro ${ }^{33}$ e para o próprio Samuel Usque, que segue cada uma de suas doutrinas, ensina que a shekinab constitui "a parte da Essência de Deus onde a luz foi diminuída a fim de permitir às almas, aos anjos e aos mundos inferiores existirem" 34 - imagem curiosamente parecida com a teoria das emanações de Plotino. Mas a shekinah, princípio feminino da manifestação de Deus, encontra-se agora no exílio, pois os pecados do povo de Israel a separam do mundo divino:

quando Israel manchou a Terra Santa com seus pecados, expulsou a Shechiná ${ }^{35}$ de sua morada e a lançou ao exílio entre outras nações. (...) Desde o momento em que a Shechiná partiu para o exílio, o pacto entre Israel e Deus foi quebrado e começou a tomar sua força do outro lado. (...) E Israel carrega as penas de todas as nações, pois Israel é o coração das nações. ${ }^{36}$

Joana, a pastora fulgurante que desencadeia em Jano uma concepção explosiva de um amor que oscila entre erotismo e espiritualidade (lembre-se a bela cena da pastora com os seios descobertos refletidos nas águas do rio), é o polo feminino de uma divindade e, nesse sentido, em termos de linguagem judaica, é a própria shekinah manifestada ao jovem pastor Jano, porém revelada e logo perdida. Portanto, trata-se da perda, ou antes, do exílio da shekinah, que os teóricos judeus vinham ensinando desde a antiga cabala medieval. Bernardim Ribeiro a interpreta como uma visão que se revela e que se perde, deixando ao pastor apenas a sensação de exílio e solidão, despertados pelo amor e pela

\footnotetext{
${ }^{33}$ Para uma confluência de linguagens místicas na obra de Bernardim Ribeiro, consulte-se o já mencionado livro de MACEDO, Do significado oculto da Menina e moça, capítulos 3 a 5 .

${ }^{34}$ O ZOHAR, p. 101.

${ }^{35}$ Há diversas variações gráficas para este termo.

${ }^{36}$ O ZOHAR, p. 103.
} 
lembrança que dele fica na memória. Parece fatalista o olhar de Bernardim sobre a condição do povo de Israel, sobretudo se consideramos que todo o desenlace dramático da experiência de Jano havia sido profetizado por Piério, pastor mais velho, aqui representando o profetismo judaico. O contemporâneo de Bernardim, Samuel Usque, na Consolação às tribulações de Israel, insistia em dizer que, na visão do profetismo, muito do sofrimento de judeus na diáspora se devia exclusivamente aos atos culposos da própria comunidade de Israel que, se agora vivia os tormentos do "desterro de Deus", é porque outrora (conforme as profecias anunciavam) a comunidade havia se entregado aos pecados da idolatria. Era essa a preocupação mais notória de Samuel Usque: Ycabo, o personagem central da Consolação, pastor cujo nome é referência anagramática a Jacob (o pastor descendente de Abraão), admite com a mais profunda tristeza que, se um dia Abraão e Moisés tinham vivido as beatitudes da esperança na terra prometida, as gerações posteriores se sujeitaram à gentilidade e às idolatrias de seus conquistadores, especialmente na diáspora, e que isso trazia agora a ira e o castigo de Deus. ${ }^{37}$ Ycabo, o pastor que se afirma como metáfora e referência da comunidade de Israel, lembra que o próprio Deus "a estranhas terras nos desviou" expressão, aliás, bastante típica dos pastores de Bernardim Ribeiro: "de estranhas terras nascidos", dirá o próprio Jano.

Joana, a pastora que desencadeia em Jano a saudade de Deus, é uma divindade aprisionada na matéria; em outros termos, a própria shekinah no exílio deste mundo. Comovente é o seu único discurso na écloga, em que ela, conversando consigo mesma, semidespida nas águas do Alentejo, compreende com amargura, pela reminiscência que o belo desperta, que a nobreza e a excelência espiritual de sua origem estão agora reduzidas à figura de uma pastora miserável que guarda patos numa terra de pobreza - curiosa representação que terá certa analogia com o

${ }^{37}$ USQUE. Consolaçam às tribulaçoens de Israel, livro I, p. xii. 
filho pródigo, por exemplo (para usar uma referência cristã), ou com as jovens princesas de contos de fadas dos sécs. XVII e XVIII, mocinhas de nobilíssima origem cumprindo míseros afazeres: "Eu guardo patas, coitada, / não sei onde isto há de ir ter. / Mais era eu pera guardada! / Que conserto foi este, ser / formosa mal empregada." 38

Trata-se de uma das mais sensíveis passagens nas éclogas de Bernardim: representação profunda e complexa, a cena realista e quase cinematográfica de Joana buscando sua imagem nas águas do rio faz convergir um conjunto de elementos típicos da cultura judaica e platônica: mistura erotismo e espiritualidade, ${ }^{39}$ põe em cena a metáfora da manifestação divina aprisionada neste mundo e simula poeticamente a reminiscência platônica (ou a saudade portuguesa, via cultura judaica) num retrato compassivo e denso da própria condição humana. A que ponto chegou a divindade exilada em nós? - terá perguntado o leitor atento à simbologia espiritualizante do poema.

Será essa a imagem inflamável que acende em Jano o amorpaixão e a dor profunda da saudade - seja da terra natal, da pátria divina, seja da própria mulher amada. O que resta ao pastor é apenas um sapato da mocinha, motivo que está igualmente na Cinderela - já que há pouco lembrávamos a analogia com as princesas de contos de fadas -, uma espécie de ícone ou fetiche, verdadeiro testemunho do bem que se perdeu. Franco, o pastor que consola Jano (estão ambos na mesma condição de desterrados e destituídos de seus amores), também cultua um objeto de reverência, a flauta que recebera de sua amada Célia: perdera-a

\footnotetext{
${ }^{38}$ RIBEIRO. Obras de... p. 240.

39 Trata-se de um elemento típico também do Zohar: "Outro traço característico do misticismo do Zohar, que marca a influência que teve na sua geração e nas subseqüentes, é a acentuada tendência ao uso de símbolos e expressões sensuais e eróticas, particularmente a união sexual, para designar verdades espirituais sublimes" (BENSION. Prefácio, p. 61).
} 
nos campos, para depois reencontrá-la, com a ajuda de seu cão. É com essa flauta que entoa a última canção da écloga. De certa forma, é outro testemunho vivo, porém aqui de um bem perdido que se recupera. Mas Jano permanece na desilusão completa e torna-se inimigo de si mesmo (metáfora também da ruptura com o pacto de Israel, conforme a visão de Samuel Usque). As circunstâncias pessoais daquele encontro com o amigo revelam, no entanto, a possibilidade de uma situação que se reverte, o exemplo vivo de uma lembrança tornada à realidade. Franco consola o amigo Jano, porque este apenas sonha com o bem perdido que o primeiro reencontrara. Não será indício de que o pastor consolado também receberá a mesma graça?

Bernardim Ribeiro, embora fatalista e quase niilista no seu olhar sobre a condição do povo de Israel, ou sobre a própria condição humana (se ampliarmos o quadro de análise do seu poema), é sempre o poeta da lamentação, mas ao mesmo tempo, da consolação, a exemplo de tantos outros livros sefarditas escritos desde o fim da Idade Média. Portanto, nem tudo é desesperança na sua poesia. $O$ "encontrar para perder" (expressão de Helder Macedo) é uma realidade para Bernardim, mas apenas em parte. Pessimista e fatalista muito embora, o poeta ainda projeta a seu pastorzinho Jano o pálido recurso da via consolatória, como fará com os pastores das demais éclogas. Alheios de si, desterrados, desiludidos no amor, nostálgicos de um passado feliz e tristemente misantropos, os míseros pastores de Bernardim se consolam. Pode não significar muito no âmbito da fábula romanesca em si (os pastores em geral se despedem ainda carregando o fardo da desilusão), mas a via consolatória assume ares proféticos e messiânicos, apenas na medida em que as éclogas poderiam ser vistas também como um livro consolatório para os judeus portugueses do exílio. "[O] que parece sem cura / às vezes o cura o tempo", dirá Fauno a seu amigo Pérsio, na écloga I. É certo que os pastores reconhecem a natureza culposa de seus erros ("Estou em tanto desvario / que não me entendo comigo", diz Jano, na 
écloga II) e, apenas por isso, compreendem, ao mesmo tempo, que a mudança no seu estado de ânimo só poderá vir deles mesmos, ou do auxílio de Deus, que jamais abandona os seus filhos. É o consolo e o conselho de Agrestes, que se lê na última écloga: "Ribeiro, tem confiança / que Deus dará de seu bem / e não percas a esperança, / pois a glória que se alcança / muitas vezes se detém". ${ }^{40}$

Este será o vestígio de um caminho consolatório que se encontra igualmente no pastor Jano. Desterrado e saudoso de um bem perdido, Jano sabe que lhe resta o difícil e doloroso caminho de volta à pátria: o sapatinho de Joana será o primeiro passo para o seu retorno.

Resumen: El presente estudio analiza algunas cuestiones históricas y filosóficas involucradas en la égloga II ("Jano e Franco") de Bernardim Ribeiro, incluida en su editio princeps publicada en 1554, en Ferrara, por iniciativa de Abraão Usque, portugués judío exiliado en Italia. Hasta el siglo 19, las églogas habían sido vistas como poesía de temática romanesca y amorosa, y sólo recientemente identificadas (juntamente con Menina e moça, romance pastoril del mismo autor) como obra de resistencia judaica. Este trabajo pretende identificar las églogas de Bernardim Ribeiro, en especial "Jano e Franco" con la obras consolatorias sefarditas tan en boga en la Península Ibérica del siglo 16, buscando su herencia literaria y política especialmente en Consolação às tribulações de Israel, de Samuel Usque, o en libros referenciales de la cabala, como el Zohar.

Palabras-clave: Renacimiento portugués; judaísmo; platonismo.

${ }^{40}$ RIBEIRO. Obras de... p. 308. 


\section{Referências}

ANDRADE, A. M. L. Os senhores do desterro: judeus portugueses em Veneza e Ferrara em meados do século XVI. Veredas, v. 6, p. 65-108, 2006. AZEVEDO, J. L. de. História dos cristãos-novos portugueses. 3. ed. Lisboa: Clássica, 1989.

BAL, G. Silêncio e contemplação: uma introdução a Plotino. São Paulo: Paulus, 2007.

BENSION, A. Prefácio. In: O ZOHAR: o livro do esplendor. Trad. Rose Mehoudar e Rita Galvão. São Paulo: Polar, 2008.

BERNARDES, J. A. C. O bucolismo português: a écloga do Renascimento e do Maneirismo. Coimbra: Livraria Almedina, 1988.

BEZERRA, C. C. Compreender Plotino e Proclo. Petrópolis: Vozes, 2006.

COSTA, D. P. da. Saudade, unidade perdida, unidade reencontrada. In: COSTA, D. P. da.; GOMES, P. Introdução à saudade: antologia teórica e aproximação crítica. Porto: Lello \& Irmãos, 1976. p. 77-155.

FRANCO, A. C. O essencial sobre Bernardim Ribeiro. Lisboa: Imprensa Nacional/ Casa da Moeda, 2007.

GOMES, P. A filosofia bebraico-portuguesa. Lisboa: Guimarães Editores, 1981.

GUIMARÃES, D. Bernardim Ribeiro (o poeta crisfal). Lisboa: Guimarães, 1908.

MACEDO, H. Do significado oculto da Menina e Moça. 2. ed. Lisboa: Guimarães, 1999.

MACEDO, H. Bernardim Ribeiro. In: MACHADO, Á. M. (Org.) Dicionário de literatura portuguesa. Lisboa: Editorial Presença, 1996.

NEPOMUCENO, L. A. Literatura e exílio: cristãos-novos na Renascença Portuguesa. Anuario de Letras, México, v. XL, p. 343-357, 2002.

O ZOHAR: o livro do esplendor. Trad. Rose Mehoudar e Rita Galvão. São Paulo: Polar, 2008.

PETRARCA, F. Letters on familiar matters (Rerum familiarium libri IXXVI). Baltimore/London: The John Hopkins University Press, 1982. 
PLATÃO. Diálogos. Trad. Edson Bini. Bauru: Edipro, 2008-2010. Vol. III: Fedro. Eutífron. Apologia de Sócrates. Críton. Fédon; Vol. V: O banquete. Mênon. Timeu. Crítias.

PLOTINO. Tratados da Enéadas. Trad. Américo Sommerman. São Paulo: Polar, 2007.

REALE, G. História da filosofia grega e romana. São Paulo: Loyola, 2008. Vol. 8: Plotino e neoplatonismo.

RIBEIRO, B. Obras completas. Ed. de Aquilino Ribeiro e M. Marques Braga. 3 ed. Lisboa: Sá da Costa, 1982. Vol. I: Menina e Moça; Vol. II: Éclogas.

RIBEIRO, B. Obras de... Ed. de Maurício Matos e Helder Macedo. Lisboa: Presença, 2010.

SANTOS, A. A écloga V de (ou sobre?) Bernardim Ribeiro. Revista da Faculdade de Letras: Linguas e Literaturas, Porto, v. XIV, p. 289-315, 1997.

SANTOS, J. T. Para ler Platão. São Paulo: Loyola, 2009. Tomo II: O problema do saber nos diálogos sobre a teoria das formas.

SARAIVA, A. J. Poesia e drama: estudos sobre Bernardim Ribeiro, Gil Vicente e as cantigas de amigo. Lisboa: Gradiva, 1996.

SOYER, F. The persecution of the Jews and Muslims of Portugal: King Manuel I and the end of religious tolerance (1496-7). Leiden: Brill, 2007.

TEIXEIRA, A B. A filosofia da saudade. Lisboa: Quidnovi, 2006.

TEIXEIRA REGO, J. Estudos e controvérsias. Lisboa: Assírio e Alvim, 1991.

UllmanN, R. A. Plotino: um estudo das Enéadas. Porto Alegre: EDIPUCRS, 2002.

USQUE, S. Consolaçam às tribulaçoens de Israel. Ed. de Mendes dos Remédios. Coimbra: França Amado, 1906-1908. 3 vols.

VASCONCELOS, C. M. de. A saudade portuguesa. Lisboa: Guimarães Editores, 1996.

Recebido para publicação em 3 de fevereiro de 2011. Aprovado em 26 de junho de 2011. 